\title{
DAMPAK FAKTOR PEMICU TERJADINYA DISPLACED COMMERCIAL RISK TERHADAP KEPUTUSAN NASABAH UNTUK TETAP MENJADI NASABAH BANK SYARIAH DI SURABAYA')
}

\author{
Yonindya Rohmatur A. \\ Program Studi S1 Ekonomi Islam-Fakultas Ekonomi dan Bisnis-Universitas Airlangga \\ Email: yonindya@gmail.com \\ Dina Fitrisia Septarini \\ Departemen Ekonomi Syariah-Fakultas Ekonomi dan Bisnis-Universitas Airlangga \\ Email: dina-f-s@feb.unair.ac.id
}

\begin{abstract}
:
The purpose of this research is to know if the three factor triggers of Displaced Commercial Risk (DCR) have affect partially to the decision of costumer to remain as the costumer of sharia bank. The method used is quantitative methods through questionnaire using likert scale by multiple linear regression analysis with reliability test and validity, classic assumption test, and hypothesis test.. The sample used is 100 sharia bank's costumer who comply the criteria sample assigned. simultaneously rate of return, bank's operational, and profit sharing expectation significantly affect to the decision of costumer, and partially the rate of return and bank's operational significantly affect to the decision of costumer, but partially the expectation of profit sharing not significantly affects to the decision of costumer.
\end{abstract}

Keywords : rate of return, bank operational, profit sharing expectation, decision of costumer

\section{PENDAHULUAN}

Bank sebagai lembaga keuangan

Perkembangan

lembaga

pada awalnya hanya merupakan tempat

penitipan harta oleh para saudagar untuk menghindari adanya kejadian

kehilangan, kecurian, ataupun bahkan perampokan selama proses perjalanan dari sebuah perdagangan. Ini pun dilakukan oleh perorangan atau pun sekelompok orang yang bersedia untuk menjaga keberadaan harta tersebut (Huda dan Heykal, 2010:23).

Dunia perbankan terus berkembang sesuai dengan kebutuhan masyarakat. Perbankan berperan menggerakan perekonomian di suatu negara. Industri perbankan berkembang pesat sehingga keberadaan bank syariah juga dinilai sangat penting untuk menggerakan perekonomian di suatu negara salah satunya di Indonesia. keuangan yang menggunakan prinsip syariah dimulai pada tahun 1992, yang diawali dengan berdirinya Bank Muamalat Indonesia (BMI) sebagai bank yang menggunakan prinsip syariah pertama di Indonesia. Sampai dengan bulan Mei 2004, perkembangan jumlah kantor bank syariah telah mencapai 353 kantor bank, dengan nilai aset sebesar 11.6 trilyun rupiah. Jumlah pembiayaan yang disalurkan mencapai 7.56 trilyun rupaih dan dana pihak ketiga sebesar 7.77 trilyun rupiah. (Direktorat Perbankan Syariah Bank Indonesia dan Institut Pertanian Bogor, 2004:1). Jumlah bank yang melakukan kegiatan usaha berdasarkan prinsip syariah pada tahun 2013 bertambah seiring dengan beroperasinya sejumlah bank baru.

\footnotetext{
1) Jurnal ini merupakan bagian dari Skripsi yang ditulis oleh Yonindya Rohmatur A.: 041211432010 yang diuji pada tanggal 9 Mei 2010
} 
Rohmatur A, et al/Jurnal Ekonomi Syariah Teori dan Terapan Vol. 3 No. 9 September 2016: 728-743; DAMPAK FAKTOR PEMICU TERJADINYA DISPLACED COMMERCIAL RISK TERHADAP KEPUTUSAN NASABAH UNTUK TETAP MENJADI

NASABAH BANK SYARIAH DI SURABAYA

Jumlah BUS tercatat tidak bertambah dari tahun sebelumnya yaitu tetap sebanyak 11 BUS, sedangkan jumlah UUS berkurang menjadi 23 UUS dengan ditutupnya UUS HSBC sebagai konsolidasi global bank induknya. Sementara itu jumlah BPRS bertambah dari 158 BPRS menjadi 163 BPRS. Penambahan jumlah BPRS tersebut bersumber dari empat izin pendirian usaha baru dan satu izin konversi dar BPR konvensional. Selain itu pada tahun 2012 juga terjadi pencabutan izin usaha satu BPRS (Statistik Perbankan Syariah Islamic Banking, www.ojk.go.id).

Seiring dengan perkembangan bank syariah, ada risiko yang selalu mengikuti. Menurut Salim, dalam Kountur (2008:6) risiko adalah ketidaktentuan (uncertainty) yang mungkin melahirkan peristiwa kerugian (loss). Ada tiga unsur penting dari sesuatu yang dianggap sebagai risiko yaitu merupakan suatu kejadian; kejadian tersebut masih merupakan kemungkinan, jadi bisa saja terjadi bisa saja tidak terjadi; jika sampai terjadi, akan menimbulkan kerugian. Risiko merupakan suatu komponen yang tidak dapat dipisahkan dari kehidupan kita, karena risiko tidak akan terpisahkan dari setiap aktivitas yang kita lakukan.

Sebagaimana firman Allah SWT dalam Surat Luqman (31) ayat 34 yang berbunyi:

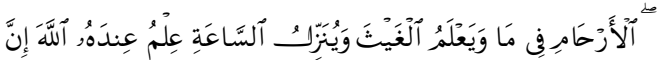

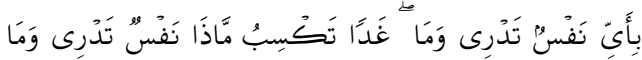

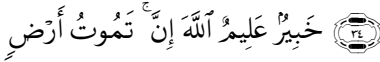

inna Ilāha indahū ilmu s-sā 'ati wayunazzilu l-ghaytha wa-ya lamu mā fi I- 'arhāmi wa-mā tadrì nafsun māżā taksibu gadan wa-mā tadrī nafsun bi'ayyi 'arḍin tamūtu 'inna llāha 'allimun khabir

Artinya: Sesungguhnya Allah SWT, hanya pada sisi-Nya sajalah pengetahuan tentang Hari Kiamat; dan Dia-lah Yang menurunkan hujan, dan mengetahui apa yang ada dalam rahim. Dan tiada seorangpun yang dapat mengetahui (dengan pasti) apa yang akan diusahakannya besok [Maksudnya: manusia itu tidak dapat mengetahui dengan pasti apa yang akan diusahakannya besok atau yang akan diperolehnya, namun demikian mereka diwajibkan berusaha]. Dan tiada seorangpun yang dapat mengetahui di bumi mana dia akan mati. Sesungguhnya Allah SWT maha mengetahui lagi maha mengenal. (Departemen Agama Rl, 2005:414)

Sebagai tambahan atas risikorisiko yang biasa dihadapi di Bank Konvensional yaitu risiko kredit, risiko pasar, risiko likuiditas, dan risiko operasional, Bank Syariah memiliki risiko-risiko unik yang hanya akan dihadapi oleh Bank Syariah yaitu Rate of return risk, Syariah Risk, dan Displaced Commercial Risk (DCR). Risikorisiko yang hanya dihadapi oleh bank syariah timbul karena bank syariah menjalankan sistemnya berdasarkan prinsip-prinsip syariah.

Menurut AAOIFI 1999 dalam Khan

dan Ahmed (2008:53) Displaced 
Rohmatur A, et al/Jurnal Ekonomi Syariah Teori dan Terapan Vol. 3 No. 9 September 2016: 728-743; DAMPAK FAKTOR PEMICU TERJADINYA DISPLACED COMMERCIAL RISK TERHADAP KEPUTUSAN NASABAH UNTUK TETAP MENJADI NASABAH BANK SYARIAH DI SURABAYA

Commercial Risk adalah transfer risiko kepada pemegang ekuitas. Risiko ini bisa muncul ketika bank berada di bawah tekanan untuk mendapatkan profit, namun bank justru harus memberikan sebagian profitnya kepada deposan Displaced Commercial Risk merupakan risiko yang paling mengancam eksistensi bank syariah karena risiko tersebut dapat mengakibatkan nasabah berpindah ke bank konvensional. Displaced Commercial Risk diakibatkan oleh beberapa faktor antara lain adanya kekhawatiran bank akan terjadinya deposan yang menarik dananya akibat rendahnya tingkat return, ketika operasional bank memiliki kinerja buruk, dan perubahan ekspektasi imbal hasil seperti suku bunga yang lebih tinggi di bank konvensional pasti akan menarik perhatian nasabah karena nasabah berpikir bahwa akan mendapatkan imbal hasil yang lebih besar dan menguntungkan. Tetapi bisa saja nasabah juga tidak tertarik dengan suku bunga yang besar karena nasabah tersebut sangat loyal terhadap bank syariah dan mencari ridho Allah SWT dengan mendapatkan keuntungan atau imbal hasil yang halal sesuai dengan syariah yaitu dengan sistem bagi hasil yang diterapkan oleh bank syariah.

Berdasarkan uraian latar belakang di atas, maka peneliti merumuskan masalah penelitian sebagai berikut: yang berhubungan dengan simpanan untuk menghindari adanya penarikan dana akibat rendahnya tingkat return . Displaced Commercial Risk dapat mengakibatkan berpindahnya nasabah bank syariah ke bank konvensional. 1. Apakah terhadap tingkat return, operasional bank, dan ekspektasi imbal hasil berpengaruh secara simultan terhadap keputusan nasabah?

2. Apakah tingkat return berpengaruh terhadap keputusan nasabah?

3. Apakah operasional bank berpengaruh terhadap keputusan nasabah?

4. Apakah ekspektasi imbal hasil berpengaruh terhadap keputusan nasabah?

Tujuan penelitian ini adalah untuk dapat mengetahui apakah tingkat return, operasional bank, dan ekspektasi imbal hasil memiliki pengaruh secara parsial terhadap keputusan nasabah untuk tetap manjadi nasabah di bank syariah serta apakah tingkat return, operasional bank, dan ekspektasi imbal hasil memiliki pengaruh secara simultan terhadap keputusan nasabah untuk tetap menjadi nasabah di bank syariah.

\section{LANDASAN TEORI}

Ismail (2010:20) mengatakan:

"bank syariah merupakan bank yang kegiatannya mengacu pada hukum Islam, dan dalam kegiatannya tidak Membebankan bunga, maupun tidak membayar bunga pada nasabah. Imbalan yang diterima oleh bank syariah, dari akad 
Rohmatur A, et al/Jurnal Ekonomi Syariah Teori dan Terapan Vol. 3 No. 9 September 2016: 728-743; DAMPAK FAKTOR PEMICU TERJADINYA DISPLACED COMMERCIAL RISK TERHADAP KEPUTUSAN NASABAH UNTUK TETAP MENJADI

NASABAH BANK SYARIAH DI SURABAYA

dan perjanjian antara nasabah dan Kountur (2008:6) menyatakan bahwa secara sederhana, risiko diartikan sebagai, kemungkinan kejadian yang merugikan. Ada tiga unsur penting dari sesuatu yang dianggap risiko:

a. Merupakan suatu kejadian.

b. Kejadian tersebut masih merupakan kemungkinan, jadi bisa saja terjadi bisa tidak terjadi.

c. Jika sampai terjadi, akan menimbulkan kerugian.

Rivai (2010:942) menyatakan bahwa Risiko dalam konteks perbankan merupakan suatu kejadian potensial, baik yang dapat dipekirakan (anticipated) maupun tidak dapat diperkirakan (unticipated) yang berdampak negative pada pendapatan maupun permodalan bank. Hastawa (2013) mengatakan:

"manusia tidak dapat memastikan apa yang akan terjadi di masa yang akan datang. Manusia hanya bisa memprediksi kerugian yang mungkin akan terjadi di masa depan. Dalam usahanya mencari nafkah, manusia dihadapkan pada kondisi yang tidak pasti. Manusia bisa merencanakan setiap kegiatan usaha dan investasi, namun manusisa tidak bisa memastikan apa yang akan didapatkan dari investasi tersebut apakah untung atau rugi. Hal ini merupakan sunatullah atau ketentuan Alah SWT."

Risiko itu sendiri merupakan fitrah yang senantiasa melekat dalam kehidupan manusia. Oleh karenanya, Islam tidak mengenal adanya transaksi bisnis tanpa risiko (Wahyudi dkk, 2013:15). bank. "

Wahyudi, dkk (2013:25) mengatakan bahwa jenis-jenis risiko yang ada di bank syariah adalah risik kredit, risiko pasar, risiko likuiditas, risiko operasional, risiko imbal hasil (Risk of Return/RoR), Risiko Komersial Displaced (Displaced Commercial Risk/DCR), dan risiko syariat.

Menurut Rosly and Zaini (2008), Sundararajan (2008), dan How dkk (2005) dalam Arshad dkk (2014) mengatakan:

Bank syariah harus mempertimbankan DCR karena masalah ini muncul karena terjadi tekanan kompettitif pada bank untuk menarik dan mempertahankan investor (penyedia dana). Jika bank syariah tidak memberikan harga yang bersaing yang serupa dengan bank lain di deposito, dan pemegang rekening investasi akan memindahkan dana mereka ke bank (syariah atau sebaliknya) yang mampu membayar harga yang lebih baik.

Menurut Mustafidah (2015) berikut adalah beberapa penyebab munculnya DCR yaitu tingkat return, operasional bank, dan ekpektasi imbal hasil.

Maski (2010:46) mengatakan:

"keputusan adalah pemilihan di antara alternatif-alternatif yang mengandung tiga pengertian, yaitu: (1) Ada pilihan atas dasar logika atau pertimbangan; (2) Ada beberapa alternatif yang harus dan dipilih salah satu yang terbaik; dan (3) Ada tujuan yang ingin dicapai, dan keputusan ini makin mendekatkan pada tujuan tersebut. Lebih lanjut, keputusan adalah suatu pengakhiran daripada proses pemikiran tentang suatu masalah atau problema untuk 
Rohmatur A, et al/Jurnal Ekonomi Syariah Teori dan Terapan Vol. 3 No. 9 September 2016: 728-743; DAMPAK FAKTOR PEMICU TERJADINYA DISPLACED COMMERCIAL RISK TERHADAP KEPUTUSAN NASABAH UNTUK TETAP MENJADI

menjawab pertanyaan apa yang harus diperbuat guna mengatasi masalah tersebut, dengan menjatuhkan pilihan pada suatu alternatif. Sejalan dengan perilaku konsumen, maka pengambilan keputusan konsumen (consumer decision makingl dapat didefinisikan sebagai suatu proses dimana konsumen melakukan penilaian terhadap berbagai alternatif pilihan, dan memilih salah satu atau lebih alternatif yang diperlukan berdasarkan pertimbanganpertimbangan tertentu."

Kriteria keputusan konsumen menurut Adisaputro (2010: 82) sebagai berikut:

1. Maksud pembelian: dibeli untuk digunakan sendiri/keluarga.

2. Tujuan yang ingin diperoleh: kegunaan atau manfaat.

3. Rasionalitas: rasional dan atau emosional.

4. Kriteria keputusan: maximum value/cost ratio, kenyamanan, kemudahan.

Berdasarkan latar belakang, rumusan masalah, tujuan penelitian, landasan teori yang telah dikemukakan maka hipotesis dalam penelitian ini adalah:

$\mathrm{H}_{01}$ : Tingkat return, operasional bank, dan ekspektasi imbal hasil secara simultan berpengaruh tidak signifikan terhadap keputusan nasabah

Hal: Tingkat return operasional bank, dan ekspektasi imbal hasil secara simultan berpengaruh signifikan terhadap keputusan nasabah
$\mathrm{H}_{02}$ : Tingkat return secara parsial berpengaruh tidak signifikan terhadap keputusan nasabah

$\mathrm{H}_{\mathrm{a} 2}$ : Tingkat return secara parsial berpengaruh signifikan terhadap keputusan nasabah

$\mathrm{H}_{03}$ : Operasional bank secara parsial berpengaruh tidak signifikan terhadap keputusan nasabah

$\mathrm{H}_{\mathrm{a} 3}$ : Operasional bank secara parsial berpengaruh signifikan terhadap keputusan nasabah

H04: Ekspektasi imbal hasil secara parsial berpengaruh tidak signifikan terhadap keputusan nasabah

$\mathrm{H}_{\mathrm{a} 4}$ : Ekspektasi imbal hasil secara parsial berpengaruh signifikan terhadap

keputusan nasabah

\section{METODE PENELITIAN}

\section{Pendekatan Penelitian}

Pendekatan yang digunakan dalam penelitian ini adalah penelitian kuantitatif. Alat analisis kuantitatif yang digunakan dalam penlitian ini adalah analisis regresi linier berganda.

\section{Variabel Eksogen}

1. Tingkat Return

Tingkat return dalam hal ini diukur dengan beberapa pertanyaan, sebagai berikut:

a. Apakah ketika tingkat imbal hasil yang anda terima mengalami penurunan maka anda akan memutuskan untuk tidak berpindah?

b. Apakah tingkat bagi hasil bank syariah menurut anda lebih menguntungkan? 
Rohmatur A, et al/Jurnal Ekonomi Syariah Teori dan Terapan Vol. 3 No. 9 September 2016: 728-743; DAMPAK FAKTOR PEMICU TERJADINYA DISPLACED COMMERCIAL RISK TERHADAP KEPUTUSAN NASABAH UNTUK TETAP MENJADI

\section{c. Apakah biaya bulanan di bank syariah lebih rendah?}

2. Operasional Bank

Operasional bank dalam hal ini diukur dengan beberapa pertanyaan, sebagai berikut:

a. Apakah bank syariah memberikan pelayanan sesuai dengan yang dijanjikan? (reliability).

b. Apakah bank syariah memberikan pelayanan yang cepat dan tepat? (responsiveness).

C. Apakah bank syariah menanamamkan rasa percaya dan keyakinan kepada para nasabah? (assurance).

d. Apakah bank syariah memberikan kemudahan dalam menghubungi bank, pelayanan yang ramah dan bersahabat? (emphaty).

3. Ekspektasi Imbal Hasil

Ekspektasi imbal hasil dalam hal ini diukur dengan beberapa pertanyaan, sebagai berikut:

a. Apakah di bank syariah anda mendapatkan pengembalian atau bagi hasil yang sesuai dengan harapan anda?

b. Jika bagi hasil yang diberikan lebih rendah dibandingkan dengan suku bunga pada bank konvensional, apakah anda akan memutuskan untuk tidak beralih ke bank konvensional?

\section{Variabel Endogen}

1. Keputusan Nasabah
Variabel keputusan nasabah untuk tetap menjadi nasabah di bank syariah disesuaikan dengan kriteria keputusan menurut Adisaputro (2010:82), yaitu:

a. Apakah biaya transaksi atau administrasi yang dibebankan oleh bank syariah rendah? (maximum value/cost ratio)

b. Apakah ketika anda memanfaatkan jasa bank syariah, anda mendapatkan manfaat yang sesuai dengan biaya yang anda kelvarkan? (maximum value/cost ratio)

c. Apakah bank syariah telah memberikan kenyamanan kepada anda? (seperti, pelayanan yang ramah, ruangan yang nyaman, dan semacamnya) (kenyamanan)

d. Apakah bank syariah telah memberikan akses yang mudah kepada anda? (seperti, ATM dan kantor cabang yang tersebar) (kemudahan)

e. Apakah bank syariah memberikan kemudahan dalam transaksi perbankannya? (kemudahan)

\section{Populasi dan Sampel}

Populasi dalam penelitian ini adalah seluruh nasabah pada bank syariah di Surabaya. Sampel dalam penelitian ini adalah 100 nasabah bank syariah di Surabaya yang memiliki rekening pada bank syariah dan bank konvensional, serta merupakan nasabah deposito. 
Rohmatur A, et al/Jurnal Ekonomi Syariah Teori dan Terapan Vol. 3 No. 9 September 2016: 728-743; DAMPAK FAKTOR PEMICU TERJADINYA DISPLACED COMMERCIAL RISK TERHADAP KEPUTUSAN NASABAH UNTUK TETAP MENJADI

\section{Jenis dan Sumber Data}

Data yang digunakan dalam penelitian ini adalah data primer. Sedangkan pengumpulan data dalam penelitian ini dilakukan dengan cara penyebaran kuisioner kepada responden.

\section{Uji Validitas dan Reliabilitas}

Jika pertanyaan berkorelasi positif dengan total skor variabel dan tingkat signifikansi di bawah 5\% atau 0,05 maka variabel dikatakan valid (Sunyoto, 2012:60).

Trihendradi (2013:201) mengatakan:

"dengan menggunakan tabel Item Total Statistics dapat digunakan untuk uji validitas dan reliabilitas sekaligus. Dengan membandingkan $r$ tabel dengan $r$ hitung (Corrected Item Total Correlation), jika $r$ hitung lebih besar dengan $r$ tabel maka pertanyaan kuesionel dikatakan valid dan reliabel. Sebaliknya, jika $r$ hitung lebih kecil dari $r$ tabel maka tidak valid dan tidak reliabel."

\section{Analisis Linier Berganda}

Teknik analisis yang digunakan dalam penelitian ini adalah regresi linier berganda dengan menggunakan metode OLS (Ordinary Least Square). Berdasarkan variabel-variabel yang digunakan, maka hubungan antar variabel dapat dinyatakan dalam fungsi sebagai berikut :

$Y=f\left(X_{1}, X_{2}, X_{3}, X_{4}\right)$

Bentuk persamaan regresi dapat dirumuskan sebagai berikut:

$Y=a+\beta_{1} X_{1}+\beta_{2} X_{2}+\beta_{3} X_{3}+e$

Dimana :

$Y=$ Keputusan nasabah

$a=$ Konstanta
$\mathrm{X}_{1}=$ Tingkat return

$X_{2}=$ Operasional bank

$\mathrm{X}_{3}=$ Ekspektasi imbal hasil

$\beta_{1 . .} \beta_{3}=$ Koefisien regresi

e $=$ Error Term/varibel pengganggu

\section{Uji Asumsi Klasik}

\section{Uji Normalitas}

Metode yang dapat digunakan untuk mendeteksi masalah normalitas data adalah uji statistik KolmogorovSminov (K-S). Menurut Widarjono (2010:111) cara pengambilan keputusan pada uji statistik non-parametik Kolmogorov-Smirnov (K-S) adalah jika data berdistribusi normal apabila nilai probabilitasnya menunjukkan nilai yang lebih besar dari tingkat signifikansi (sig > $0,05)$ sedangkan jika data tidak berdistribusi normal apabila nilai probabilitasnya menunjukkan nilai yang lebih kecil dari tingkat signifikansi (sig < $0,05)$.

\section{Uji Heteroskedastisitas}

Untuk menguji heteroskedastisitas pada model regresi, dapat dilakukan dengan menggunakan metode korelasi spearman. Menurut Widarjono (2010:89) dasar pengambilan keputusan pada uji heteroskedastisitas adalah jika nilai signifikansi lebih besar dari 0,05 (nilai sig > 0,05), maka tidak terjadi heteroskedastisitas, sedangkan jika nilai signifikansi lebih kecil dari 0,05 (nilai sig < $0,05)$, maka terjadi heteroskedastisitas.

\section{Uji Multikolinearitas}

Uji multikolinearitas dapat dilihat dari nilai tolerance atau Variance Inflation 
Rohmatur A, et al/Jurnal Ekonomi Syariah Teori dan Terapan Vol. 3 No. 9 September 2016: 728-743; DAMPAK FAKTOR PEMICU TERJADINYA DISPLACED COMMERCIAL RISK TERHADAP KEPUTUSAN NASABAH UNTUK TETAP MENJADI

NASABAH BANK SYARIAH DI SURABAYA

Factor (VIF). Semakin besar nilai VIF maka diduga terdapat multikolinearitas antar variabel independen. Menurut Widarjono (2010:81) ketentuan dari uji multikolinearitas adalah jika nilai VIF lebih besar dari 10 dan tolerance semakin mendekati 0 , maka diduga terjadi multikolinearitas, sedangkan jika nilai VIF lebih kecil dari 10 dan tolerance semakin mendekati 1, maka diduga tidak terjadi multikolinearitas.

\section{Uji Autokorelasi}

Menurut Sunyoto (2012:121) salah satu ukuran dalam menentukan ada tidaknya masalah autokorelasi dengan uji Durbin-Watson (DW) dengan ketentuan sebagai berikut:

a. Terjadi autokorelasi positif, jika nilai DW dibawah -2 (DW < -2)

b. Tidak terjadi autokorelasi, jika DW diantara -2 dan +2 atau $-2 \leq \mathrm{DW} \leq+2$

c. Terjadi autokorelasi negatif jika nilai DW di atas +2 atau $\mathrm{DW}>+2$

\section{Uji Hipotesis}

\section{Uji F (F-test)}

Menurut Widarjono (2010:24)
prosedur yang dilakukan dalam
melakukan uji F ini adalah:
hipotesis nol $\left(\mathrm{H}_{\circ}\right)$ dan hipotesis alternatif $\left(\mathrm{H}_{a}\right)$.

$\mathrm{H}_{01}=$ Variabel tingkat return, operasional bank, dan ekspektasi imbal hasil secara simultan berpengaruh tidak signifikan terhadap keputusan nasabah.
$\mathrm{H}_{\mathrm{al}}=$ Variabel tingkat return, operasional bank, dan ekspektasi imbal hasil secara simultan berpengaruh signifikan terhadap keputusan nasabah.

b. Menentukan daerah penerimaan uji $F$ dengan kriteria jika nilai signifikan $\leq$ 0,05 maka $\mathrm{Hal}_{\mathrm{al}}$ diterima. Ini berarti secara simultan semua variabel independen berpengaruh secara signifikan terhadap variabel dependen. Jika nilai signifikan > 0,05 maka $\mathrm{H}_{01}$ diterima. Ini berarti secara simultan semua variabel independen tersebut tidak mempunyai pengaruh yang signifikan terhadap variabel dependen.

\section{Uji + ( $t$-test)}

Menurut Widarjono (2010:28) prosedur yang dilakukan dalam melakukan uji T adalah sebagai berikut:

a. Membuat rumusan hipotesis, yaitu hipotesis nol $\left(H_{\circ}\right)$ dan hipotesis alternatif $\left(\mathrm{H}_{\mathrm{a}}\right)$.

$\mathrm{H}_{02,3,4}=$ Variabel tingkat return, operasional bank, dan ekspektasi imbal hasil secara parsial berpengaruh tidak signifikan terhadap keputusan nasabah.

$\mathrm{H}_{\mathrm{a} 2,3,4}=$ Variabel tingkat return, operasional bank, dan ekspektasi imbal hasil secara parsial berpengaruh signifikan terhadap keputusan nasabah.

b. Menentuan daerah penerimaan uji $\dagger$ dengan kriteria jika nilai signifikan $\leq$ 0,05 maka $\mathrm{H}_{a 2,3,4}$ diterima. Ini berarti 
Rohmatur A, et al/Jurnal Ekonomi Syariah Teori dan Terapan Vol. 3 No. 9 September 2016: 728-743; DAMPAK FAKTOR PEMICU TERJADINYA DISPLACED COMMERCIAL RISK TERHADAP KEPUTUSAN NASABAH UNTUK TETAP MENJADI

NASABAH BANK SYARIAH DI SURABAYA

secara parsial variabel independen tersebut mempunyai pengaruh yang signifikan terhadap variabel dependen. Jika nilai signifikan >0,05 maka $\mathrm{H}_{02,3,4}$ diterima. Ini berarti secara parsial variabel independen tersebut tidak mempunyai pengaruh yang signifikan terhadap variabel dependen.

\section{Koefisien Determinasi}

Koefisien determinasi

digunakan untuk mengukur persentase total variasi variabel dependen yang dijelaskan oleh variabel independen dalam garis regresi (Widarjono, 2010:19). Besarnya nilai koefisien determinasi terletak antara 0 dan 1, $\left(0 \leq R^{2} \leq 1\right)$ yang mana semakin mendekati l berarti semakin baik garis regresi. Sehingga, nilai $R^{2}$ yang kecil berarti kemampuan variabel-variabel independen dalam menjelaskan variabel dependen sangat terbatas.

\section{HASIL DAN PEMBAHASAN}

\section{Uji Validitas dan Reliabilitas}

Dari Tabel 1 uji validitas variabel penelitian menunjukkan bahwa variabel eksogen yaitu karakter tingkat return, operasional bank, dan ekspektasi menunjukkan hasil yang valid. Hal tersebut tercermin melalui hasil koefisien korelasi pearson yang positif dan nilai signifikansi yang kurang dari 0,05 . Hasil yang sama juga terdapat pada variabel endogen yaitu keputusan nasabah dimana pada pengujian validitas menunjukkan hasil koefisien korelasi pearson yang positif dan nilai signifikansi yang kurang dari 0,05 . Hasil tersebut menunjukkan bahwa indikator yang digunakan valid dan dapat digunakan untuk pengukuran suatu penelitian.

Tabel 1.

Uji Validitas Variabel Penelitian

\begin{tabular}{|c|c|c|c|c|c|}
\hline $\begin{array}{c}\text { Variab } \\
\text { el }\end{array}$ & $\begin{array}{l}\text { Ind } \\
\text { ika } \\
\text { tor }\end{array}$ & $\begin{array}{c}\text { Koefis } \\
\text { ien } \\
\text { Korel } \\
\text { asi } \\
\text { Pears } \\
\text { on }\end{array}$ & $\begin{array}{l}\text { Sig } \\
\text { nifi } \\
\text { ka } \\
\text { nsi }\end{array}$ & Kriteria & $\begin{array}{c}\text { Keter } \\
\text { anga } \\
n\end{array}$ \\
\hline \multirow{3}{*}{$\begin{array}{l}\text { Tingkat } \\
\text { return } \\
\left(X_{1}\right)\end{array}$} & $\mathrm{X}_{1} \mathrm{a}$ & 0,675 & $\begin{array}{l}0,0 \\
00\end{array}$ & $\begin{array}{l}<0,05 \\
\text { positif }\end{array}$ & Valid \\
\hline & $\mathrm{X}_{1} \mathrm{~b}$ & 0,713 & $\begin{array}{l}0,0 \\
00\end{array}$ & $\begin{array}{l}<0,05 \\
\text { positif }\end{array}$ & Valid \\
\hline & $\mathrm{X}_{1} \mathrm{c}$ & 0,704 & $\begin{array}{l}0,0 \\
00\end{array}$ & $\begin{array}{l}<0,05 \\
\text { positif }\end{array}$ & Valid \\
\hline \multirow{4}{*}{$\begin{array}{c}\text { Opera } \\
\text { sional } \\
\text { Bank } \\
\left(X_{2}\right)\end{array}$} & $\mathrm{X}_{2} \mathrm{a}$ & 0,708 & $\begin{array}{l}0,0 \\
00\end{array}$ & $\begin{array}{l}<0,05 \\
\text { positif }\end{array}$ & Valid \\
\hline & $\mathrm{X}_{2} \mathrm{~b}$ & 0,779 & $\begin{array}{l}0,0 \\
00\end{array}$ & $\begin{array}{l}<0,05 \\
\text { positif }\end{array}$ & Valid \\
\hline & $\mathrm{X}_{2} \mathrm{C}$ & 0,732 & $\begin{array}{l}0,0 \\
00\end{array}$ & $\begin{array}{l}<0,05 \\
\text { positif }\end{array}$ & Valid \\
\hline & $\mathrm{X}_{2} \mathrm{~d}$ & 0,776 & $\begin{array}{l}0,0 \\
00\end{array}$ & $\begin{array}{l}<0,05 \\
\text { positif }\end{array}$ & Valid \\
\hline \multirow{2}{*}{$\begin{array}{c}\text { Ekspek } \\
\text { tasi } \\
\text { Imbal } \\
\text { Hasil } \\
\left(X_{3}\right)\end{array}$} & $\mathrm{X}_{3} \mathrm{a}$ & 0,769 & $\begin{array}{l}0,0 \\
00\end{array}$ & $\begin{array}{l}<0,05 \\
\text { positif }\end{array}$ & Valid \\
\hline & $\mathrm{X}_{3} \mathrm{~b}$ & 0,877 & $\begin{array}{l}0,0 \\
00\end{array}$ & $\begin{array}{l}<0,05 \\
\text { positif }\end{array}$ & Valid \\
\hline \multirow{5}{*}{$\begin{array}{l}\text { Keputu } \\
\text { san } \\
\text { Nasab } \\
\text { ah }(Y)\end{array}$} & $\mathrm{Ya}$ & 0,695 & $\begin{array}{l}0,0 \\
00\end{array}$ & $\begin{array}{l}<0,05 \\
\text { positif }\end{array}$ & Valid \\
\hline & $\mathrm{Yb}$ & 0,691 & $\begin{array}{l}0,0 \\
00\end{array}$ & $\begin{array}{l}<0,05 \\
\text { positif }\end{array}$ & Valid \\
\hline & $Y c$ & 0,533 & $\begin{array}{l}0,0 \\
00\end{array}$ & $\begin{array}{l}<0,05 \\
\text { positif }\end{array}$ & Valid \\
\hline & $\mathrm{Yd}$ & 0,745 & $\begin{array}{l}0,0 \\
00\end{array}$ & $\begin{array}{l}<0,05 \\
\text { positif }\end{array}$ & Valid \\
\hline & Ye & 0,709 & $\begin{array}{l}0,0 \\
00\end{array}$ & $\begin{array}{l}<0,05 \\
\text { positif }\end{array}$ & Valid \\
\hline
\end{tabular}

Sumber: Data diolah

Dari Tabel 2 uji reliabilitas variabel penelitian menunjukkan bahwa variabel eksogen yaitu karakter tingkat return, operasional bank, dan ekspektasi menunjukkan hasil yang reliabel. Hal 
Rohmatur A, et al/Jurnal Ekonomi Syariah Teori dan Terapan Vol. 3 No. 9 September 2016: 728-743; DAMPAK FAKTOR PEMICU TERJADINYA DISPLACED COMMERCIAL RISK TERHADAP KEPUTUSAN NASABAH UNTUK TETAP MENJADI

NASABAH BANK SYARIAH DI SURABAYA

tersebut tercermin melalui hasil koefisien korelasi ( $r$ ) antara skor item dengan skor total variabel yang menunjukan nilai positif serta lebih besar dari 0,1946. Hasil yang sama juga terdapat pada variabel endogen yaitu keputusan nasabah dimana pada pengujian reliabilitas menunjukkan koefisien korelasi ( $r$ ) positif dan lebih besar dari 0,1946. Hasil tersebut menunjukkan bahwa indikator yang digunakan reliabel dan dapat digunakan untuk pengukuran suatu penelitian.

Tabel 2.

Uji Reliabilitas Variabel Penelitian

\begin{tabular}{|c|c|c|c|c|}
\hline $\begin{array}{c}\text { Varia } \\
\text { bel }\end{array}$ & $\begin{array}{l}\text { Indik } \\
\text { ator }\end{array}$ & $\begin{array}{c}\text { Correct } \\
\text { ed item } \\
\text { total } \\
\text { correlat } \\
\text { ion }\end{array}$ & Kriteria & $\begin{array}{c}\text { Ketera } \\
\text { ngan }\end{array}$ \\
\hline \multirow{3}{*}{$\begin{array}{c}\text { Tingk } \\
\text { at } \\
\text { return } \\
\left(X_{1}\right)\end{array}$} & $\mathrm{X}_{1} \mathrm{a}$ & 0,245 & $\begin{array}{c}> \\
0,1946\end{array}$ & $\begin{array}{c}\text { Reliab } \\
\text { el }\end{array}$ \\
\hline & $\mathrm{X}_{1} \mathrm{~b}$ & 0,360 & $\begin{array}{c}> \\
0,1946\end{array}$ & $\begin{array}{c}\text { Reliab } \\
\text { el }\end{array}$ \\
\hline & $\mathrm{X}_{1} \mathrm{c}$ & 0,271 & $\begin{array}{c}> \\
0,1946\end{array}$ & $\begin{array}{c}\text { Reliab } \\
\text { el }\end{array}$ \\
\hline \multirow{4}{*}{$\begin{array}{c}\text { Oper } \\
\text { asion } \\
\text { al } \\
\text { Bank } \\
\left(X_{2}\right)\end{array}$} & $\mathrm{X}_{2} \mathrm{a}$ & 0,487 & $\begin{array}{c}> \\
0,1946\end{array}$ & $\begin{array}{c}\text { Reliab } \\
\text { el }\end{array}$ \\
\hline & $\mathrm{X}_{2} \mathrm{~b}$ & 0,578 & $\begin{array}{c}> \\
0,1946\end{array}$ & $\begin{array}{c}\text { Reliab } \\
\text { el }\end{array}$ \\
\hline & $\mathrm{X}_{2} \mathrm{c}$ & 0,499 & $\begin{array}{c}> \\
0,1946\end{array}$ & $\begin{array}{c}\text { Reliab } \\
\text { el }\end{array}$ \\
\hline & $\mathrm{X}_{2} \mathrm{~d}$ & 0,563 & $\begin{array}{c}> \\
0,1946\end{array}$ & $\begin{array}{c}\text { Reliab } \\
\text { el }\end{array}$ \\
\hline \multirow{2}{*}{$\begin{array}{c}\text { Ekspe } \\
\text { ktasi } \\
\text { Imbal } \\
\text { Hasil } \\
\left(X_{3}\right)\end{array}$} & $\mathrm{X}_{3} \mathrm{a}$ & 0,365 & $\begin{array}{c}> \\
0,1946\end{array}$ & $\begin{array}{c}\text { Reliab } \\
\text { el }\end{array}$ \\
\hline & $\mathrm{X}_{3} \mathrm{~b}$ & 0,365 & $\begin{array}{c}> \\
0,1946\end{array}$ & $\begin{array}{c}\text { Reliab } \\
\text { el }\end{array}$ \\
\hline \multirow{5}{*}{$\begin{array}{l}\text { Keput } \\
\text { usan } \\
\text { Nasa } \\
\text { bah } \\
\text { (Y) }\end{array}$} & Ya & 0,451 & $\begin{array}{c}> \\
0,1946\end{array}$ & $\begin{array}{c}\text { Reliab } \\
\text { el }\end{array}$ \\
\hline & $\mathrm{Yb}$ & 0,541 & $\begin{array}{c}> \\
0,1946\end{array}$ & $\begin{array}{c}\text { Reliab } \\
\text { el }\end{array}$ \\
\hline & Yc & 0,290 & $\begin{array}{c}> \\
0,1946\end{array}$ & $\begin{array}{c}\text { Reliab } \\
\text { el }\end{array}$ \\
\hline & Yd & 0,486 & $\begin{array}{c}> \\
0,1946\end{array}$ & $\begin{array}{c}\text { Reliab } \\
\text { el }\end{array}$ \\
\hline & Ye & 0,535 & $\begin{array}{c}> \\
0,1946\end{array}$ & $\begin{array}{c}\text { Reliab } \\
\text { el }\end{array}$ \\
\hline
\end{tabular}

Sumber: Data diolah

\section{Uji Asumsi Klasik}

\section{Uji Normalitas}

Hasil pengujian normalitas dalam penelitian ini dapat dilihat pada tabel 3 menunjukkan bahwa nilai probabilitasnya sebesar 0,181 berarti lebih dari tingkat signifikansi 0,05 sehingga variabel berdistribusi normal.

Tabel 3.

Uji Normalitas

One-Sample Kolmogorov-Smirnov Test

\begin{tabular}{|c|c|c|}
\hline & & $\begin{array}{l}\text { Unstandardize } \\
\text { d Residual }\end{array}$ \\
\hline $\mathrm{N}$ & Mean & $\begin{array}{r}100 \\
0 E-7\end{array}$ \\
\hline Normal & Std. & \\
\hline Parametersa,b & $\begin{array}{l}\text { Deviatio } \\
\text { n }\end{array}$ & .22281316 \\
\hline & & 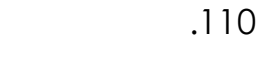 \\
\hline $\begin{array}{l}\text { Most Extreme } \\
\text { Differences }\end{array}$ & Positive & .055 \\
\hline (n) & $\begin{array}{l}\text { Negativ } \\
\text { e }\end{array}$ & -.110 \\
\hline $\begin{array}{l}\text { Kolmogorov-S } \\
\text { Asvmp Sig }\end{array}$ & & $\begin{array}{r}1.096 \\
181\end{array}$ \\
\hline
\end{tabular}

a. Test distribution is Normal.

b. Calculated from data.

Sumber: Data Olahan SPSS

Statistics Version 20

\section{Uji Heteroskedastisitas}

Hasil pengujian heteroskedastisitas dalam penelitian ini dapat dilihat pada tabel 4 menunjukkan bahwa nilai signifikansinya masing-masing adalah $\mathrm{X}_{1}$ sebesar 0,346 berarti lebih dari 0,05, $\mathrm{X}_{2}$ sebesar 0,068 berarti lebih dari 0,05, dan $\mathrm{X}_{3}$ sebesar 0,469 berarti lebih dari 0,05, sehingga semua variabel tidak terjadi heteroskedastisitas. 
Rohmatur A, et al/Jurnal Ekonomi Syariah Teori dan Terapan Vol. 3 No. 9 September 2016: 728-743; DAMPAK FAKTOR PEMICU TERJADINYA DISPLACED COMMERCIAL RISK TERHADAP KEPUTUSAN NASABAH UNTUK TETAP MENJADI

Tabel 4.

Coefficientsa

Uji Heteroskedastisitas

\begin{tabular}{|c|c|c|c|c|c|c|}
\hline \multirow{2}{*}{\multicolumn{2}{|c|}{ Model }} & \multicolumn{2}{|c|}{$\begin{array}{c}\text { Unstandardized } \\
\text { Coefficients }\end{array}$} & $\begin{array}{c}\text { Standardized } \\
\text { Coefficients }\end{array}$ & \multirow[t]{2}{*}{$\dagger$} & \multirow[t]{2}{*}{ Sig. } \\
\hline & & B & Std. Error & Beta & & \\
\hline \multirow{4}{*}{1} & (Constant) & -.013 & .139 & & -.096 & .924 \\
\hline & $X 1$ & -.040 & .042 & -.118 & -.947 & 346 \\
\hline & $\mathrm{X} 2$ & .072 & .039 & (191 & 1.848 & .068 \\
\hline & $x 3$ & .024 & .032 & .093 & .727 & .469 \\
\hline
\end{tabular}

a. Dependent Variable: ABSRES

Sumber: Data Olahan SPSS Statistics Version 20

Uji Multikolinearitas

Hasil pengujian heteroskedastisitas dalam penelitian ini dapat dilihat pada tabel 5 menunjukkan bahwa $X_{1}$ memiliki nilai VIF sebesar 1,570 yang berarti lebih kecil dari 10 dan nilai tolerance sebesar 0,637 yang semakin mendekati $1, X_{2}$ memiliki VIF sebesar 1,081 yang berarti

Tabel 5

Uji Multikolinearitas

Coefficients $^{a}$

\begin{tabular}{|c|c|c|c|c|c|c|c|c|}
\hline \multirow{2}{*}{\multicolumn{2}{|c|}{ Model }} & \multicolumn{2}{|c|}{$\begin{array}{c}\text { Unstandardized } \\
\text { Coefficients }\end{array}$} & \multirow{2}{*}{$\begin{array}{c}\text { Standardized } \\
\text { Coefficients } \\
\text { Beta }\end{array}$} & \multirow[t]{2}{*}{$\dagger$} & \multirow[t]{2}{*}{ Sig. } & \multicolumn{2}{|c|}{ Collinearity Statistics } \\
\hline & & $\mathrm{B}$ & Std. Error & & & & Tolerance & VIF \\
\hline \multirow{4}{*}{1} & $\begin{array}{l}\text { (Constan } \\
\text { t) }\end{array}$ & 311 & .221 & & 1.407 & .163 & & \\
\hline & $\mathrm{x} 1$ & .362 & .066 & .436 & 5.452 & .000 & .637 & 1.570 \\
\hline & $\mathrm{x} 2$ & .435 & .062 & .463 & 6.976 & .000 & .925 & 1.081 \\
\hline & $\times 3$ & .090 & .052 & .142 & 1.738 & .085 & .609 & 1.641 \\
\hline
\end{tabular}

a. Dependent Variable: $Y$

Uji Autokorelasi

Hasil pengujian autokorelasi dalam penelitian ini dapat dilihat pada tabel 6 menunjukkan bahwa nilai Durbin-Watson (DW) sebesar 1,634 ini berarti nilai DW berada diantara -2 dan +2 sehingga tidak terjadi autokorelasi. 
Rohmatur A, et al/Jurnal Ekonomi Syariah Teori dan Terapan Vol. 3 No. 9 September 2016: 728-743; DAMPAK FAKTOR PEMICU TERJADINYA DISPLACED COMMERCIAL RISK TERHADAP KEPUTUSAN NASABAH UNTUK TETAP MENJADI

Tabel 6.

Uji Autokorelasi

Model Summaryb

\begin{tabular}{|l|c|c|c|c|c|}
\hline $\begin{array}{l}\text { Mo } \\
\text { del }\end{array}$ & $R$ & $\begin{array}{c}R \\
\text { Squ } \\
\text { are }\end{array}$ & $\begin{array}{c}\text { Adju } \\
\text { sted } \\
R \\
\text { Squ } \\
\text { are }\end{array}$ & $\begin{array}{c}\text { Std. } \\
\text { Error of } \\
\text { the } \\
\text { Estima } \\
\text { te }\end{array}$ & Durbin- \\
Watson \\
\hline 1 & $.780^{a}$ & .609 & .597 & .226 & 1.634 \\
\hline
\end{tabular}

a. Predictors: (Constant), X3, X2, X1

b. Dependent Variable: $Y$

Sumber: Data Olahan SPSS Statistics

Version 20

Analisis Regresi Linier Berganda

Hasil pengolahan data dalam analisis regresi linier berganda yang dilakukan dengan menggunakan SPSS Statistics Version 20 menghasilkan output seperti pada tabel 7.

Tabel 7.

Regresi Linier Berganda

Coefficientsa

\begin{tabular}{|ll|r|r|}
\hline \multirow{2}{*}{ Model } & \multicolumn{2}{|c|}{$\begin{array}{c}\text { Unstandardized } \\
\text { Coefficients }\end{array}$} \\
\cline { 3 - 4 } & (Constan & B & Std. Error \\
\hline \multirow{3}{*}{1 t) } & .311 & .221 \\
X1 & .362 & .066 \\
& X2 & .435 & .062 \\
& X3 & .090 & .052 \\
\hline
\end{tabular}

a. Dependent Variable: $Y$

Sumber: Data Olahan SPSS Statistics

Version 20

Berdasarkan tabel 7, model yang

terbentuk dari regresi linier berganda

adalah:

$Y=a+\beta_{1} X_{1}+\beta_{2} X_{2}+\beta_{3} X_{3}+e$

$Y=0,311+0,362 X_{1}+0,435 X_{2}+0,090$

$X_{3}$

\section{Uji Hipotesis}

\section{Uji F (F-test)}

Hasil pengujian uji $F$ dalam penelitian ini dapat dilihat pada tabel 8 menunjukkan nilai signifikansi $\mathrm{X}_{1}, \mathrm{X}_{2}$, dan $\mathrm{X}_{3}$ adalah sebesar 0,000 yang berarti nilai signifikansinya lebih kecil dari 0,05 sehingga $\mathrm{H}_{01}$ ditolak dan $\mathrm{H}_{\mathrm{a} 4}$ diterima yang berarti variabel tingkat return, operasional bank, dan ekspektasi imbal hasil secara simultan berpengaruh signifikan terhadap keputusan nasabah.

Tabel 8.

Uji F (F-test)

\section{ANOVAa}

\begin{tabular}{|l|r|r|r|r|l|}
\hline Model & $\begin{array}{c}\text { Sum of } \\
\text { Squar } \\
\text { es }\end{array}$ & df & $\begin{array}{r}\text { Mean } \\
\text { Squar } \\
\text { e }\end{array}$ & $F$ & Sig. \\
\hline $\begin{array}{l}\text { Regressi } \\
\text { on }\end{array}$ & 7.653 & 3 & 2.551 & $\begin{array}{r}49.8 \\
25\end{array}$ & $.000^{\mathrm{b}}$ \\
$\begin{array}{l}\text { Residual } \\
\text { Total }\end{array}$ & $\begin{array}{r}4.915 \\
12.568\end{array}$ & $\begin{array}{r}96 \\
99\end{array}$ & .051 & & \\
\hline
\end{tabular}

a. Dependent Variable: $Y$

b. Predictors: (Constant), X3, X2, X1

Sumber: Data Olahan SPSS Statistics

Version 20

Uji † (t-test)

Berdasarkan pengujian pada Tabel 9 maka dapat disimpulkan Nilai signifikansi $X_{1}$ adalah sebesar 0,000 yang berarti nilai signifikansi $\mathrm{X}_{1}$ lebih kecil dari 0,05 sehingga $\mathrm{H}_{02}$ ditolak dan $\mathrm{H}_{\mathrm{a} 2}$ diterima yang berarti variabel tingkat return secara parsial berpengaruh signifikan terhadap keputusan nasabah. Nilai signifikansi $\mathrm{X}_{2}$ adalah sebesar 0,000 yang berarti nilai signifikansi $\mathrm{X}_{2}$ lebih kecil dari 0,05 sehingga $\mathrm{H}_{03}$ ditolak dan $\mathrm{H}_{\mathrm{a} 3}$ diterima yang berarti variabel operasional bank secara parsial berpengaruh signifikan terhadap keputusan nasabah. Nilai signifikansi $X_{3}$ adalah sebesar 0,085 yang berarti nilai signifikansi $\mathrm{X}_{3}$ lebih besar dari 0,05 sehingga $\mathrm{H}_{04}$ diterima dan $\mathrm{H}_{\mathrm{a} 4}$ ditolak yang berarti variabel operasional bank 
Rohmatur A, et al/Jurnal Ekonomi Syariah Teori dan Terapan Vol. 3 No. 9 September 2016: 728-743; DAMPAK FAKTOR PEMICU TERJADINYA DISPLACED COMMERCIAL RISK TERHADAP KEPUTUSAN NASABAH UNTUK TETAP MENJADI NASABAH BANK SYARIAH DI SURABAYA

secara parsial berpengaruh tidak signifikan terhadap keputusan nasabah.

Tabel 9.

Uji $\dagger$ (t-test)

Coefficientsa

\begin{tabular}{|c|c|c|c|c|c|}
\hline \multirow[t]{2}{*}{ Model } & \multicolumn{2}{|c|}{\begin{tabular}{|c|}
$\begin{array}{c}\text { Unstandar } \\
\text { dized } \\
\text { Coefficien } \\
\text { ts }\end{array}$ \\
\end{tabular}} & \multirow{2}{*}{\begin{tabular}{|c|}
$\begin{array}{c}\text { Standar } \\
\text { dized } \\
\text { Coeffici } \\
\text { ents }\end{array}$ \\
Beta \\
\end{tabular}} & \multirow[t]{2}{*}{$\dagger$} & \multirow[t]{2}{*}{ Sig. } \\
\hline & $B$ & $\begin{array}{l}\text { Std. } \\
\text { Error }\end{array}$ & & & \\
\hline $\begin{array}{l}\text { (Cons } \\
\text { tant) }\end{array}$ & .311 & .221 & & 1.407 & .163 \\
\hline$X 1$ & .362 & .066 & .436 & 5.452 & .000 \\
\hline$x 2$ & .435 & .062 & .463 & 6.976 & .000 \\
\hline$x 3$ & .090 & .052 & .142 & 1.738 & .085 \\
\hline
\end{tabular}

a. Dependent Variable: $Y$

Sumber: Data Olahan SPSS Statistics Version 20

\section{Koefisien Determinasi $\left(R^{2}\right)$}

Dari tabel 10 diperoleh hasil nilai koefisien determinasi $\left(R^{2}\right)$ sebesar 0,609 atau $60,9 \%$. Angka tersebut menunjukkan bahwa variabel keputusan nasabah dapat dijelaskan oleh variabel tingkat return, operasional bank, dan ekspektasi imbal hasil sebesar 60,9\%. Sedangkan sisanya yaitu $39,1 \%$ dipengaruhi oleh variabel lain yang termasuk dalam penelitian ini.

Tabel 10.

Koefisien Determinasi

Model Summaryb

\begin{tabular}{|l|c|r|r|r|}
\hline $\begin{array}{l}\text { Mod } \\
\text { el }\end{array}$ & $R$ & $\begin{array}{c}\text { R } \\
\text { Square }\end{array}$ & $\begin{array}{l}\text { Adjusted R } \\
\text { Square }\end{array}$ & $\begin{array}{c}\text { Std. Error } \\
\text { of the } \\
\text { Estimate }\end{array}$ \\
\hline 1 & $.780 a$ & .609 & .597 & .226 \\
\hline
\end{tabular}

a. Predictors: (Constant), X3, X2, X1

b. Dependent Variable: $Y$

Sumber: Data olahan SPSS Statistics Version 20

\section{PEMBAHASAN}

Hasil penelitian menunjukkan bahwa variabel tingkat return, operasional bank, dan ekspektasi imbal hasil bersamasama memiliki pengaruh yang signifikan terhadap keputusan nasabah. Hal tersebut dapat dilihat dari nilai signifikansi yang dihasilkan, yaitu sebesar 0,000 . Nilai signifikansi tersebut lebih kecil dari 0,05 sehingga $\mathrm{H}_{01}$ ditolak, artinya variabel tingkat return, operasional bank, dan ekspektasi imbal hasil secara simultan berpengaruh signifikan terhadap variabel keputusan nasabah. Hasil pengujian uji $F$ tersebut mendukung penelitian terdahulu oleh Mustafidah (2015) yang mengatakan bahwa ketiga variabel tersebut yaitu tingkat return, operasional bank, dan ekspektasi imbal hasil merupakan faktor pemicu terjadinya DCR. Sebagai seorang muslim, sebaiknya dalam melakukan semua kegiatannya selalu mentaati aturan syariat agar mendapatkan ridho dari Allah SWT. Sebagai seorang muslim, juga tidak diperbolehkan hanya mencari keuntungan material saja, namun juga harus mencari ridho Allah SWT. hal tersebut sesuai dengan firman Allah SWT pada QS. Al-Israa':19) yang berbunyi:

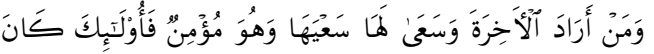

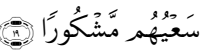

wa-man 'arāda l-'ākhirata wa-sa 'ā lahā sa 'yahā wa-huwa mu 'minun fa'ulā ỉka kāna sa yuhum mashkūran Artinya: "Dan barangsiapa menghendaki kehidupan akhirat dan berusaha kearah itu sungguhsungguh, sedangkan dia beriman, maka mereka itulah orang yang usahanya dibalas dengan baik." (Departemen Agama Rl, 2005:284).
Hasil
penelitian
menunjukkan

bahwa variabel tingkat return memiliki 
Rohmatur A, et al/Jurnal Ekonomi Syariah Teori dan Terapan Vol. 3 No. 9 September 2016: 728-743; DAMPAK FAKTOR PEMICU TERJADINYA DISPLACED COMMERCIAL RISK TERHADAP KEPUTUSAN NASABAH UNTUK TETAP MENJADI NASABAH BANK SYARIAH DI SURABAYA

pengaruh yang signifikan terhadap keputusan nasabah. Hal tersebut dapat dilihat dari nilai signifikansi yang dihasilkan, yaitu sebesar 0,000. Nilai signifikansi tersebut lebih kecil dari 0,05 sehingga $\mathrm{H}_{02}$ ditolak, artinya variabel tingkat return secara parsial berpengaruh signifikan terhadap variabel keputusan nasabah. Nasabah pada bank syariah akan tetap menggunakan jasa bank syariah jika suatu saat tingkat return bank syariah kurang bersaing dengan bank konvensional karena beberapa nasabah bank syariah memilih untuk mendapatkan ridho dari Allah SWT meskipun mendapatkan return yang sedikit. Nasabah tersebut telah menjadi nasabah yang loyal, hal tersebut sesuai dengan firman Allah SWT pada QS. Al-Baqarah 278-279 yang memerintahkan umat islam untuk tidak memakan riba supaya mendapatkan ridho dari Allah SWT:

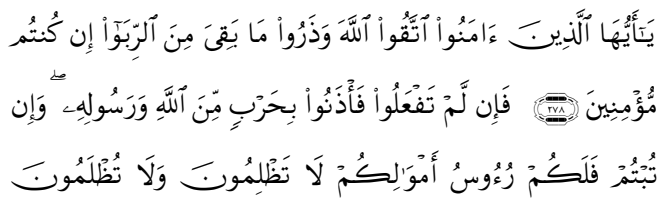

yā-'ayyuhā lladhina 'āmanū ttaqū llāha wa-dharū mā baqiya mina r-ribā in kuntum mu'minina (278) fa- in lam taf 'alū fa-'dhanū bi-harbin mina Ilāhi wa-rasūlihì wa-'in tubtum fa-lakum ru'ūsu 'amwālikum lā tazlimūna wa-lā tuzlamūna (279)

Artinya:"Hai orang-orang beriman, bertakwalah kepada Allah dan tinggalkan sisa riba (yang belum dipungut) jika kamu orang-orang yang beriman. Maka, Allah dan Rasul-Nya akan menerangimu. Dan jika kamu bertobat (dari pengambilan riba) maka pokok hartamu; kamu tidak menganiaya dan tidak dianiaya (Departemen Agama Rl, 2005:47).

Hasil dari pengujian uji † variabel $\mathrm{X}_{1}$ terhadap $Y$ tersebut mendukung penelitian terdahulu oleh labal dan Greuning (2008), Ismail (2010) dalam Arshad, dkk (2014) yang mengatakan bahwa dalam jangka pendek rate of return yang rendah tidak berpengaruh signifikan untuk memaksa deposan untuk menarik dana. Tetapi, dalam jangka panjang akan berpengaruh signifikan untuk deposan menarik dananya dari bank syariah.

Hasil penelitian menunjukkan bahwa variabel operasional bank memiliki pengaruh yang signifikan terhadap keputusan nasabah. Hal tersebut dapat dilihat dari nilai signifikansi yang dihasilkan, yaitu sebesar 0,000 . Nilai signifikansi tersebut lebih kecil dari 0,05 sehingga $\mathrm{H}_{03}$ ditolak, artinya variabel operasional bank secara parsial berpengaruh signifikan terhadap variabel keputusan nasabah. Hasil pengujian $t$ pada variabel $X_{2}$ terhadap $Y$ tersebut mendukung penelitian terdahulu oleh Normawati (2013) mengatakan bahwa kualitas pelayanan berpengaruh positif signifikan terhadap loyalitas nasabah. Hal ini menunjukkan baik buruknya kualitas layanan yang diberikan oleh perbankan syariah akan memiliki pengaruh yang sangat besar terhadap loyalitas nasabahnya. Hal tersebut sesuai dengan firman Allah SWT di dalam QS. Al-Imran ayat 159: 
Rohmatur A, et al/Jurnal Ekonomi Syariah Teori dan Terapan Vol. 3 No. 9 September 2016: 728-743; DAMPAK FAKTOR PEMICU TERJADINYA DISPLACED COMMERCIAL RISK TERHADAP KEPUTUSAN NASABAH UNTUK TETAP MENJADI

NASABAH BANK SYARIAH DI SURABAYA

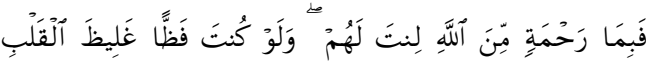

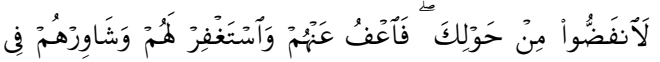

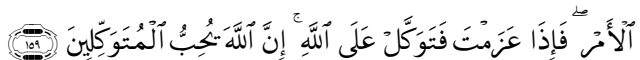

fa-bi-mā rahmatin mina llāhi linta lahum wa-law kunta fazzan ghaliza lqalbi la-nfaḍu $\min$ hawlika fa- fu anhum wa-staghfir lahum washāwirhum fì l-'amri fa-'idhā 'azamta fa-tawakkal 'alā llāhi 'inna llāha yuhibbu I-mutawakkilina

Artinya:"Maka disebabkan rahmat dari Allah-lah kamu berlaku lemah lembut terhadap mereka. Sekiranya kamu bersikap keras lagi berhati kasar, tentulah mereka menjauhkan diri dari sekililingmu. Karena itu maafkanlah mereka, mohonkanlah ampun bagi mereka, dan bermusyawaralah dengan mereka dalam urusan itu. Kemudian apabila kamu telah membulatkan tekad, maka bertawakallah kepada Allah. Sesungguhnya Allah menyukai orangorang yang bertawakal kepadaNya." (Departemen Agama RI, 2005:71).

Hasil penelitian menunjukkan

bahwa variabel operasional bank memiliki pengaruh yang signifikan terhadap keputusan nasabah. Hal tersebut dapat dilihat dari nilai signifikansi yang dihasilkan, yaitu sebesar 0,085. Nilai signifikansi tersebut lebih besar dari 0,05 sehingga $\mathrm{H}_{14}$ ditolak, artinya variabel operasional bank secara parsial berpengaruh tidak signifikan terhadap variabel keputusan nasabah. Nasabah harus selalu berprasangka baik dan dilarang untuk berprasangka buruk kepada apa yang akan terjadi, hal tersebut sesuai dengan firman Allah SWT pada QS. Al-Hujurat ayat 12:

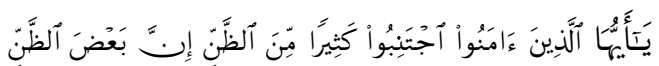

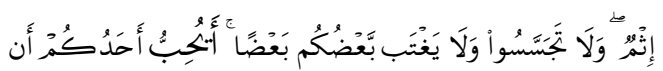

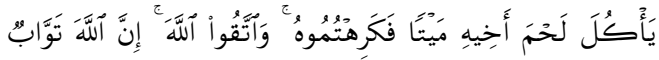

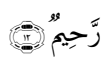

yā-'ayyuhā lladhīna 'āmanū jtanibū kathîran mina z-zanni inna ba 'da $z$ zanni 'ithmun wa-lā tajassasū wa-lā yaghtab ba 'dukum ba'dan 'a-yuhibbu 'ahadukum 'an ya 'kula lahma 'akhini maytan fa-karihtumūhu wa-ttaqū llāha 'inna llāha tawwābun rahịmun Artinya: "Wahai orang-orang yang beriman, jauhilah kenyakan dari prasangka, sesungguhnya sebagian prasangka itu adalah dosa. Janganlah kamu mencari-cari kesalahan orang lain dan janganlah sebagian kamu menggunjing sebagian yang lain. Sukakah salah seorang di antara kamu memakan daging saudaranya yang sudah mati? Maka, tentulah kamu merasa jijik kepadanya. Dan, bertakwalah kepada Allah. Sesungguhnya Allah Maha Penerima tobat lagi Maha Penyayang." (Departemen Agama RI, 2005:517).

Hasil pengujian $†$ pada variabel $X_{3}$ terhadap $Y$ tersebut mendukung penelitian terdahulu oleh Normawati (2013) yang mengatakan bahwa pengetahuan tentang bagi hasil tidak berpengaruh terhadap loyalitas nasabah.

\section{SIMPULAN}

Simpulan dari penelitian pengaruh ini adalah sebagai berikut:

1. Faktor pemicu terjadinya displaced commercial risk yang terdiri dari tingkat return, operasional bank, dan ekspektasi imbal hasil secara simultan berpengaruh positif signifikan terhadap keputusan nasabah. 
Rohmatur A, et al/Jurnal Ekonomi Syariah Teori dan Terapan Vol. 3 No. 9 September 2016: 728-743; DAMPAK FAKTOR PEMICU TERJADINYA DISPLACED COMMERCIAL RISK TERHADAP KEPUTUSAN NASABAH UNTUK TETAP MENJADI

2. Variabel tingkat return secara parsial berpengaruh positif signifikan terhadap keputusan nasabah dengan nilai $\dagger$ sebesar 5,452 dan nilai signifikansi $0,000 \leq 0,05$.

3. Variabel operasional bank secara parsial berpengaruh positif signifikan terhadap keputusan nasabah dengan nilai t sebesar 6,976 dan nilai signifikansi $0,000 \leq 0,05$.

4. Variabel ekpektasi imbal hasil secara parsial berpengaruh positif tidak signifikan terhadap keputusan nasabah dengan nilai $\dagger$ sebesar 1,738 dan nilai signifikansi 0,085 $\geq 0,05$.

\section{DAFTAR PUSTAKA}

Adisaputro, Gunawan. 2010. Manajemen Pemasaran Analisis untuk Perancangan Strategi Pemasaran. Yogyakarta: Sekolah Tinggi llmu Manajemen YKPN

Arshad, Noraziah Che, dkk. 2014. Determinants of Displaced Commercial Risk in Islamic Banking Institutions: Malaysia Evidence. Vol. 13. No. 2. Hal. 205-217

Departemen Agama Republik Indonesia.2005. Al-Quran dan Terjemah. Bandung: Diponegoro

Departemen Agama Republik Indonesia.2005. Al-Quran dan Terjemah. Bandung: Diponegoro

Direktorat Perbankan Syariah Bank Indonesia dan Institut Pertanian Bogor. 2004. Potrnsi, Preferensi dan Perilau Masyarakat terhadap Bank Syariah di Wilayah Kalimantan Selatan. (online) (www.bi.go.id, diakses 16 Januari 2015)

Hastawa, Adam. 2013. Pandangan islam terhadap risiko. (slideshare online), (http://www.slideshare.net/AdamHasta wa/pandangan-islam-terhadap-resiko). Diakses pada tanggal 12-11-2015 pukul 09.00

Huda, Nurul dan Mohammad Heykal. 2010. Lembaga Kevangan Islam.
Jakarta: PT. Kencana Prenada Media Group

Ismail. 2010. Manajemen perbankan: dari teori menuju aplikasi. Jakarta:kencana prenada media group

Khan, Tariqullah dan Habib Ahmed.2008.Manajemen Risiko Lembaga Keuangan Syariah. Jakarta timur: PT. Bumi Aksara

Kountur, Ronny. 2008. Mudah Memahami Manajemen Risiko Perusahaan. Jakarta: PPM

Kountur, Ronny. 2008. Mudah Memahami Manajemen Risiko Perusahaan. Jakarta: PPM

Maski, Ghozali. 2010. Analisis Keputsan Nasabah Menabung: Pendekatan Komponen dan Model Logistik Studi Pada Bank Syariah di Malang. Journal of Indonesian Applied Economic. Vol. 4. No. 1. Hal 43-57

Mustafidah, Wiwit. 2015. Proses Manajemen Risiko Terhadapt Displaced Commercial Risk pada Bank Syariah Mandiri KC Banyuwangi. Skripsi Tidak Diterbitkan. Surabaya Universitas Airlangga

Otoritas Jasa Keuangan, 2015. Statistik Perbankan Syariah Islamic Banking Statistics, (online), (www.ojk.go.id, diakses 3 September 2015)

Rivai, Veitthzal. 2010. Islamic Banking. Sistem bank islam bukan hanya solusi menghadapi krisis namun solusi dalam menghadapi berbagai persoalan perbankan dan ekonomi global. Jakarta: Bumi Aksara

Sunyoto, Danang. 2012. Validitas dan Reliabilitas. Yogyakarta: Nuha Medika

Trihendradi, C. 2013. Langkah Mudah Menguasai SPSS 21. Yogyakarta: C.V Andi Offsets

Wahyudi, Imam dkk. 2013. Manajemen Risiko Bank Islam. Jakarta: Salemba Empat

Widarjono, Agus. 2010. Analisis Statistik Multivariat Terapan. Yogyakarta: Sekolah Tinggi IImu Manajemen YKPN 